Proceedings

\title{
Evolutionary Biological Responses of Pikas (Lagomorpha, Mammalia) to Past Insular Ecosystems (Miocene-Holocene): A Key for the Management of Extant Species ${ }^{\dagger}$
}

\author{
Blanca Moncunill-Solé 1,2
}

Citation: Moncunill-Solé, B.

Evolutionary Biological Responses

of Pikas (Lagomorpha, Mammalia)

to Past Insular Ecosystems

(Miocene-Holocene): A Key for the Management of Extant Species.

Proceedings 2021, 65, $\mathrm{x}$.

https://doi.org/10.3390/xxxxx

Published: date

Publisher's Note: MDPI stays neutral with regard to jurisdictional claims in published maps and institutional affiliations.

Copyright: (c) 2021 by the authors. Submitted for possible open access publication under the terms and conditions of the Creative Commons Attribution (CC BY) license (http://creativecommons.org/licenses/by/4.0/).
1 Dipartimento di Scienze, Università degli Studi Roma Tre, 00146 Rome, Italy; blanca.moncunill@udc.es or blanca.moncunill@gmail.com; Tel.: +34-881-012-101

2 Centro de Investigacións Científicas Avanzadas (CICA), Universidade da Coruña, 15071 A Coruña, Spain

† Presented at the 1st International Electronic Conference on Biological Diversity, Ecology, and Evolution, 1531 March 2021.

\begin{abstract}
Fossil biotas provide an opportunity to explore eco-evolutionary adaptations to insular regimes not subjected to the anthropogenic perturbations. Historically, these studies have been biased towards large-sized taxa, and less efforts has been devoted to small ones. For this reason, the present study reviews the general and specific biological responses described in extinct insular ochotonids (Ochotonidae, Lagomorpha) from the Mediterranean Islands (Miocene-Holocene), given the last cutting-edge investigations. Parallel biological trends have been observed in these species, regarding an increase of adult body size, teeth modifications (e.g., higher hypsodonty), slow-gear lifestyle with new locomotion skills (related to digging, climbing or leaping), as well as a slow life history. Most of these features are also noticed in other extinct insular micromammals and largesized species. Although a single ochotonid dwells in true insular environments at present, the future climate change will push them to inhabit top of mountains (ecological islands). The present paper provides useful baseline data (evolutionary history of the family, biological abilities or responses to insularity) for the design and implementation of innovative and effective management actions.
\end{abstract}

Keywords: conservation paleobiology; fossil record; island rule; life history; Mediterranean islands

\section{Introduction}

Islands are regarded as natural laboratories and constitute a serie of evolutionary repeatable and testable experiments [1]. Their mammalian dwellers are characterized by a set of distinguishing biological traits, which have evolved as predictable responses to the selective regimes of islands [2-6]. On one hand, the 'island rule' is defined as the biological trend for small mammals to evolve towards larger sizes (giants), whereas largesized taxa evolve towards smaller morphotypes (dwarfs) [2-5]. Several authors have noticed that it is a more widespread trend than suspected initially, which is not solely limited to mammals. In this regard, other taxonomic groups, such as birds, reptiles or invertebrates, follow this ecogeographical rule (with few exceptions) [7,8]. On the other hand, the 'island syndrome' also states biological shifts in these taxa, regarding the demography, life history, behavior or morphology, when compared to mainland forerunners [6]. Ecologists have proposed three specific ecological factors as the main drivers of these biological parallel patterns: resource limitation, low predation and high intra-specific competition $[4,5,9,10]$. However, others have suggested alternative explanations based on the relative importante of the lower extrinsic mortality rate and limited resource availability on species life history [11]. Particularly, extinct insular endemics have aroused special interest, mainly because their biology and ecology were not perturbed by anthropogenic 
actions [12]. In addition to size shifts, extinct insular endemics are characterized, in general, by changes in postcranial bones (proportions, length, robustness, articulation loss), dentition alterations (higher degree of hypsodonty, loss of premolars, more complex enamel pattern), as well as modifications in skull and brain (absence of pneumatization, short muzzles, brain and sense organs reduction) [13]. However, such results are biased (overrepresented by large mammals), and the eco-evolutionary adaptations of small mammals to insular regimes are relatively less known.

Lagomorpha is an evolutionary successful order of intermediate size, occurring in a wide range of habitats with a worldwide distribution. Ecologically, rabbits, hares and pikas play essential roles in ecosystems, representing the base of some predator-prey systems and supporting their communities (such as foxes, birds of prey or coyotes), impacting on hydrology and soil biology and modelling plant communities [14]. For this reason, lagomorphs were also common in exinct insular faunas. In Mediterranean Islands various lagomorph species have been identified (both ochotonids, O; and leporids, L): Gymnesicolagus gelaberti ( $\mathrm{O}$, but see Figure 1), Hypolagus balearicus (L), Hypolagus peregrinus (L), Nuralagus rex $(\mathrm{L})$, Paludotona etruria $(\mathrm{O}$, but see Figure 1$)$, Paludotona minor $(\mathrm{O}$, but see Figure 1), Prolagus apricenicus $(\mathrm{O})$, Prolagus figaro $(\mathrm{O})$, Prolagus imperialis $(\mathrm{O})$, Prolagus sardus $(\mathrm{O})$, and Sardolagus obscurus (L) (Figure 1) [15-24]. At date, these ochotonid species are the only ones recovered in extinct insular ecosystems. Currently a single ochotonid taxon (Ochotona hyperborea) inhabits true islands, but some others occur in ecological ones [25].

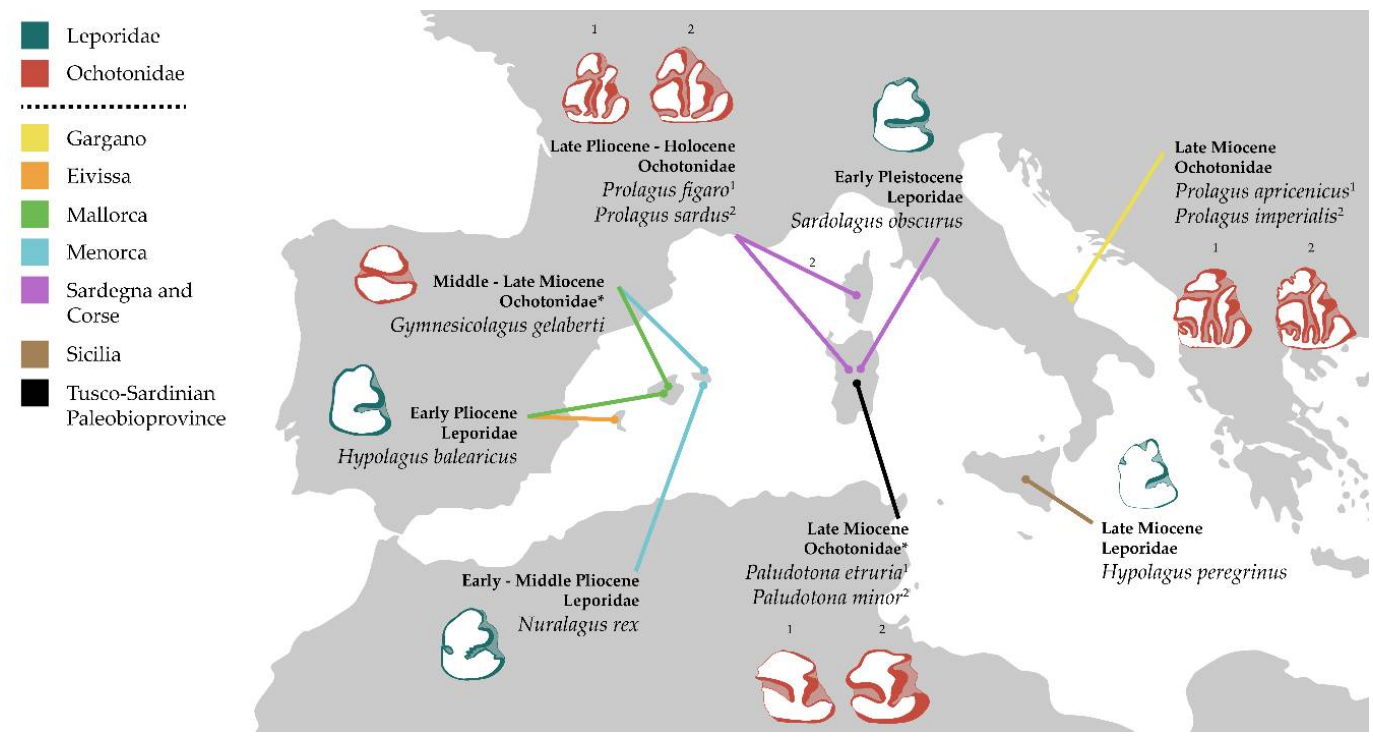

Figure 1. Distribution of extinct lagomorphs in the Mediterranean Islands. Geographic location, geologic age, taxonomic details (family and species), as well as illustration of right p3 (no scale) are provided for each taxa. * Although Gymnesicolagus and Paludotona are considered to be ochotonids in the present paper, some recent studies identify them as stem-lagomorphs $[23,26]$.

Considering the above background, the present paper has the main objective of reviewing the eco-evolutionary adaptations of extinct ochotonids (Lagomorpha, Ochotonidae) to insular regimes. The results will contribute to: (1) enhancing the paleobiological knowledge of past lagomorphs, and (2) understanding the biological responses of small mammals to insular ecosystems. Moreover, the exposed conclusions may give clues to address the management and conservation of extant ochotonids, which will be largely affected by climate change according to species distribution models.

\section{Experiments}


The present research is a review of the paleobiological data derived from previous investigations and studies in the extinct ochotonid taxa that dwelled in insular ecosystems. To this end, the data was gathered accurately from peer-reviewed published papers carried out by several authors [18,23,27-38], as well as from very recent unpublished results. Taxonomic details (species and family), geographic distribution and geologic age of the assessed ochotonids are provided in Figure 1. Paleobiological information of insular leporids or micromammalian taxa (rodents and soricids) was also gathered for comparative purposes [13,37]. With the same objective, material of extant lagomorph species (housed at the Hungarian Natural History Museum) was also assessed. 100\% stacked bar plots (showing relative percentages) have been used to compare evo-evolutionary adaptations between insular ochotonids and other micromammalian groups.

\section{Results} 1.

The paleobiological data of Mediterranean extinct ochotonids is summarized in Table

Table 1. Eco-evolutionary adaptations described in extinct ochotonids from the Mediterranean Islands (Miocene-Holocene). Abbreviations: 仓: high; Љ: low; >: increase; ?: unknown; ¿: doubtful.

\begin{tabular}{|c|c|c|c|c|}
\hline Species & $\begin{array}{c}\text { Body Mass } \\
(\mathrm{g})\end{array}$ & Dental Features & Locomotion & $\begin{array}{c}\text { Life } \\
\text { History }\end{array}$ \\
\hline $\begin{array}{l}\text { Gymnesicolagus } \\
\text { gelaberti }\end{array}$ & ¿5400 & $\begin{array}{l}\text { Hypselodonty } \\
\text { and hypsodonty }{ }^{1}\end{array}$ & $?$ & ? \\
\hline Paludotona minor & ? & $\begin{array}{l}\text { Hypselodonty, hypsodonty, } \\
\text { and }>\text { masticatory area }\end{array}$ & $?$ & $?$ \\
\hline Paludotona etruria & $?$ & $\begin{array}{l}\text { Hypselodonty, hypsodonty, } \\
\text { and }>\text { masticatory area }\end{array}$ & ? & $?$ \\
\hline $\begin{array}{l}\text { Prolagus } \\
\text { apricenicus }\end{array}$ & $150-250$ & $\begin{array}{l}\text { Hypselodonty, } \sqrt{ } \text { hypsodonty, } \\
\text { 仓 enamel pattern, and } \\
\text { > premolar area }\end{array}$ & $\begin{array}{l}\text { Non-cursorial, } \\
\text { jumping skills }\end{array}$ & Slow \\
\hline Prolagus imperialis & $500-750$ & $\begin{array}{c}\text { Hypselodonty, } \sqrt{ } \text { hypsodonty, } \\
\text { 仓ै enamel pattern, and } \\
\text { > premolar area }\end{array}$ & $\begin{array}{l}\text { Non-cursorial, } \\
\text { jumping skills }\end{array}$ & $?$ \\
\hline Prolagus figaro & $398-436$ & $\begin{array}{l}\text { Hypselodonty, } \sqrt{ } \text { hypsodonty, } \\
\text { i enamel pattern, > premolar } \\
\text { area, and megadontia }\end{array}$ & $?$ & $?$ \\
\hline Prolagus sardus & $504-525$ & $\begin{array}{l}\text { Hypselodonty, î hypsodonty, } \\
\sqrt{\Omega} \text { enamel pattern, > premolar } \\
\text { area }^{2} \text {, and megadontia }\end{array}$ & $\begin{array}{l}\text { Non-cursorial, } \\
\text { jumping and } \\
\text { digging skills }\end{array}$ & ¿Slow \\
\hline
\end{tabular}

${ }^{1}$ This trait is not observed in all teeth. ${ }^{2}$ To a lesser degree than other Prolagus species.

\subsection{Body Mass}

The body mass of extant pikas ranges between $70-250 \mathrm{~g}$, whereas leporids are much heavier (from half a kilo to nearly $5 \mathrm{~kg}$ ) [34]. Extinct insular Prolagus ( 150-750 g, depending on the species) and G. gelaberti $(5400 \mathrm{~g})$ were larger than extant ochotonids (Table 1) [30,33-35]. At present, the weights of Paludotona species have not been estimated, but their teeth dimensions suggest a smaller size than P. imperialis [23]. The degree of body size shift of insular species is assessed by means of $S_{i}$ (=mass of insular population/mass of mainland forerunners) [37]. The strong modifications experienced by insular species prevent, in most of the cases, to determine certaintly the direct ancestor of these taxa, but several approximations have been done using contemporany continental relatives [37,38]. Following the 'island rule', these results indicate a shift towards larger morphotypes ( $\left.\mathrm{S}_{\mathrm{i}} \sim 2.27-35.82\right)$. In extant insular leporids, the 'island rule' is quite complex 
and a clear pattern is not observed. Some taxa have evolved towards a large size ( $\mathrm{S}_{\mathrm{i}}$ max. $\sim 1.5-1.6)$, whereas others have become dwarfs $\left(S_{i} \min . ~ \sim 0.4-0.5\right)$ [5].

\subsection{Dental Features}

Several modifications have been identified in the dentition of insular ochotonids, regarding hypselodonty (ever-growing teeth), hypsodonty (high crowned teeth), complexity of enamel pattern, and increase of occlusal surface area (cited as masticatory area, premolar area and/or megadontia) (Table 1). Gymnesicolagus gelaberti has a hypselodont dentition, with some hypsodont upper teeth (although this latter feature has not been assessed quantitatively) $[18,30]$. The taxon also shows a short snout and a short mandibular diastema, as well as it lacks m3. These have been considered archaic traits, suggesting that they are not related to insular regimes [30]. The hypselodont dentition of Paludotona species has higher crown teeth (lacking a quantitative assessment too). Although this genus also shows some archaic features, an increase of the masticatory surface is noted as a response to insular regimes [16,23]. Regarding Prolagus species, all of them are characterized by an hypselodont dentition. Some taxa (P. apricenicus, P. imperialis, and P. figaro) have low hypsodonty combined with a high complexity of the enamel pattern, whereas, on the other hand, P. sardus shows the opposite traits (high hypsodont dentition with a poor complex enamel pattern). An increase of premolar area is noticed in all the taxa, but to a lesser degree in P. sardus [28]. Sardinian Prolagus are also characterized by megadontia (an increase of the occlusal area of postcanine dentition relative to body mass).

\subsection{Locomotion}

In general, the lifestyle of extinct insular ochotonids has been little studied (Table 1). The postcranium of the Garganic ochotonids (P. apricenicus and P. imperialis) is similar to that of extant talus pikas. Such resemblance suggest jumping skills and a reduction of cursoriality in these extinct taxa [35]. On the other hand, P. sardus has more upright position of the head and a greater range of movements than extant relatives. Their postcranial morphology also lacks cursorial skills, but shows adaptations to jumping, digging and climbing [27].

\subsection{Life History}

The life history of extinct species is studied by means of histological analyses of bones. As it is an invasive technique, this has only been carried out in P. apricenicus so far. A minimum longevity of 7 years is suggested for this species, what means a long live relative to its body size. For this reason, specialists describe that this species moved towards the slow-end of the 'fast-slow continuum' of the life history variation [34]. In addition, paleopathological incidence can also shed light on the species life history. In the present case, several abnormal conditions have been identified in P. sardus, although the incidence of pathologies in mainland taxa is very low. As pathologies are more frequent in species with a longer life, this high incidence in the insular taxon could be interpreted as an extended life relative to mainland forerunners [35,36].

\section{Discussion}

\subsection{Eco-Evolutionary Adaptations of Small Mammals to Islands: Comparisons and Drivers}

Ochotonids show clear eco-evolutionary respones to insular regimes [35]. However, when they are compared to other small insular taxa, the patterns are not so homogenous (Figure 2) [13]. Comparatively, extinct ochotonids are the small mammals from Mediterranean area that have been best paleobiologically described. This contrasts with soricids for which neither locomotor nor life history studies have been carried out at date. 

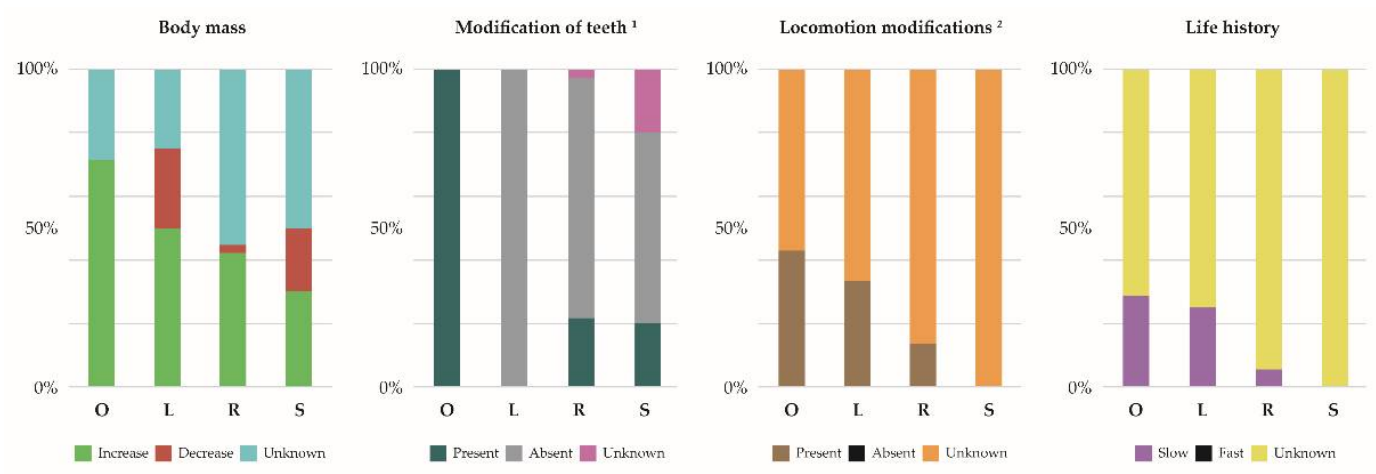

Figure 2. Comparison of the eco-evolutionary adaptations described in the most important micromammalian taxa from Mediterranean Islands (Miocene-Holocene): $\mathrm{O}$, ochotonids $(\mathrm{N}=7) ; \mathrm{L}$, leporids $(\mathrm{N}=4)$; $\mathrm{R}$, rodents $(\mathrm{N}=37)$; and $\mathrm{S}$, soricids $(\mathrm{N}=10)$. Data was obtained from present study and previous publications [13]. ${ }^{1}$ Hypsodonty, enamel pattern complexity, masticatory surface and/or tooth loss. ${ }^{2}$ Non-cursorial locomotion, with fossorial, jumping and/or climbing skills.

Generally speaking, extinct small mammals experience an increase of body mass following the 'island rule' (Figure 2). Although they show a huge size, in most of the cases this value has not been compared to the size of their direct ancestors [13,39]. Therefore, these results should be taken with caution. In some cases it is documented that small species do not follow the 'island rule', showing a similar size than their forerunners (e.g., Mus minotaurus from Crete), or even becoming dwarves [40]. According to Palkovacs [11], body size modifications of insular endemics depend on the extent to which low extrinsic mortality and limitation of resources affect to their life history. Small mammals, generally, are more affected by the lower extrinsic mortality, driving to an increase of age at maturity and a larger size. However, in such island where micromammals experience a strong resource limitation, these selective pressures will trigger a dwarf morphotype.

All insular species of ochotonids show modifications of their dentitions, what contrasts with observations in leporids (Figure 2). In rodents and soricids the \% of teeth modifications is rather small. These discrepancies could be consequence of the fact that teeth have only been examined by taxonomical purposes, and some features (e.g., hypsodonty index) have been neither considered nor quantified. However, the shifts documented in ochotonids and some other taxa are also identified in large-sized endemics [13]. These have been related to a more abrasive diet triggered by the arid resource-limited place where they dwell $[28,41]$. However, such features also increase the longevity of the teeth, and might respond to other biological and ecological stressors (e.g., extended life) [23].

Little is known about the locomotion and life history of small-sized endemics (Figure 2). The few studies show that they evolved towards a slow-gear locomotion with digging, leaping and/or climbing skills. The absence of carnivorous predators, the strong limitation of resources and the orography of Mediterranean Islands were the main drivers of such traits [42]. In these conditions, selection favores a more stable and resistent skeleton, which allowed them to explore different environments and establish in new ecological niches $[43,44]$ and to search underground resources when limitations are very strict $[13,42]$. In relation to life history, small-sized endemics moved towards the slow-end of the life-history continuum, as consequence of the low extrinsic mortality that occurs in insular regimes [11]. In this regard, according to this hypothesis, Hypnomys onicensis shows similar growth rate but a more extended life than extant relatives [45]. In the case of largemammals, they also evolved towards a slower life history [13].

\subsection{Past Insular Ochotonids: A Key for the Management of Extant Species}

The recent modelizations of the coming climate change and its consequences on extant ecosystems and biotas suggest that more than two-thirds of lagomorph species will be affected [46]. Specially, ochotonids will be profound impacted, experiencing marked range declines, and will be forced to move towards high-altitude areas. In some cases, 
these new climatic conditions will finally push species to extinction [46]. On the other hand, most of leporids will migrate to maintain their current ecological niche towards high latitudinal regions as consequence of their larger sizes [46]. Knowing the ecological and biological variables of extant ochotonids (e.g., adult body size or litter size), as well as understanding how these species respond to environmental changes at evolutionary level, are essential keys for design effective mitigation measures and conservation protocols.

The conservation paleobiology tries to use long-term paleobiological data of past species to know their evolutionary responses to environmental changes, and to address the conservation and management of extant species [47]. In this regard, the present study provides baseline data describing how ochotonids responded to insularity in the past. As discussed above, climate change will contract the range of pikas, and most of them will be restricted in ecological islands (top-mountain regions) [48]. This ecological isolation will prevent them to move to nearby regions, and will increase their susceptibility to decline [46]. Results highlight the successful adaptation of ochotonids to insular regimes, even showing some long-lasting lineages. Moreover, all groups showed very similar predictable responses, including dental morphology, locomotor attributes, body size and life history (Table 1, Figure 2). These features will have to be carefully reviewed to face with the management of extant threatened ochotonids, allowing to identify suitable candidates or to evaluate assisted relocations for some of them. In this regard, Ochotona princeps is very resilient in front of warmer conditions, changing its foraging tactics and adjustment its activity cycle. However, their isolated populations have been removed due to their limited dispersion [48].

\section{Conclusions}

The present paper reviews the eco-evolutionary adaptations of past ochotonids to insular regimes (Miocene-Holocene, Mediterranean Islands). All examined species responded with similar biological shifts. Besides increasing their adult body size, they also experienced changes in teeth, lifestyle and life history. This set of adaptations have also been identified in other micromammalian taxa from insular habitats. The present study provides baseline data that might be useful for conservation purposes. As consequence of climate change, extant pikas will be threatened and will be restricted to small regions (ecological islands). Knowing which are the eco-evolutionary responses of ochotonids to these ecological stressors (insularity) could be decisive in the design of effective management.

Acknowledgments: This research was supported by the Consellería de Cultura, Educación e Ordenación Universitaria, Xunta de Galicia, Spain (ED481B 2018/046) and SYNTHESYS+ Project Funding (HU-TAF-1206). Special thanks to Chiara Angelone and Alejandro Blanco for their advices.

Institutional Review Board Statement: Not applicable

Informed Consent Statement: Not applicable

Data Availability Statement: Not applicable

Conflicts of Interest: The author declares no conflict of interest.

\section{References}

1. Whittaker, R.J.; Fernández-Palacios, J.M. Island Biogeography: Ecology, Evolution and Conservation, 2nd ed.; Oxford University Press: Oxford, UK, 2007.

2. Foster, J.B. Evolution of mammals on islands. Nature 1964, 202, 234-235.

3. Van Valen, L. Pattern and the balance of nature. Evol. Theory 1973, 1, 31-49.

4. Lomolino, M.V. Body size of mammals on islands: The island rule reexamined. Am. Nat. 1985, 125, 310-316.

5. Lomolino, M.V. Body size evolution in insular vertebrates: Generality of the island rule. J. Biogeogr. 2005, 32, 1638-1699, doi:10.1111/j.1365-2699.2005.01314.x.

6. Adler, G.H.; Levins, R. The island syndrome in rodent populations. Q. Rev. Biol. 1994, 69, 473-490.

7. Clegg, S.M.; Owens, I.P.F. The "island rule" in birds: Medium body size and its ecological explanations. Proc. R Soc. B 2002, 269, 1359-1365, doi:10.1098/rspb.2002.2024. 
8. McClain, C.R.; Boyer, A.; Rosenberg, G. The island rule and the evolution of body size in the deep sea. J. Biogeogr. 2006, 33, 15781584, doi:10.1111/j.1365-2699.2006.01545.x.

9. Grant, P.R. Patterns on islands and microevolution. In Evolution on Islands, 1st ed.; Grant, P.R., Ed.; Oxford University Press: Oxford, UK, 1997; pp. 1-17.

10. McNab, B.K. Minimizing energy expenditure facilitates vertebrate persistence on oceanic islands. Ecol. Lett. 2002, 5, 693-704, doi:10.1046/j.1461-0248.2002.00365.x.

11. Palkovacs, E.P. Explaining adaptive shifts in body size on islands: A life history approach. Oikos 2003, 103, 37-44, doi:10.1034/j.1600-0706.2003.12502.x.

12. Masseti, M. Mammals of the Mediterranean islands: Homogenization and the loss of biodiversity. Mammalia 2009, 73, 169-202, doi:10.1515/MAMM.2009.029.

13. Van der Geer, A.A.E. Parallel patterns and trends in functional structures in extinct island mammals. Integr. Zool 2014, 9, 167182, doi:10.1111/1749-4877.12066.

14. Chapman, J.A.; Flux, J.E.C. Rabbits, Hares and Pikas. Status Survey and Conservation Action Plan, 1st ed.; International Union for Conservation of Nature and Natural Resources: Gland, Switzerland, 1990.

15. Wagner, J.A. Über die Knochenbrekzie in Sardinien und die darin gefundenen Thiere, so wie über einige andere hieher gehörige Erscheinungen. Archiv. Ges. Natur. 1829, 15, 10-31.

16. Dawson, M.R. Paludotona etruria, a new ochotonid from the Pontian of Tuscany. Verh. Naturforsch Ges. Basel 1959, $70,157-166$.

17. López-Martínez, N.; Thaler, L. Biogéographie, évolution et complements à la systématique du groupe d'Ochotonides PiezodusProlagus (Mammalia, Lagomorpha). Bull Soc. Géol Fr Série 7 1975, 17, 850-866.

18. Mein, P.; Adrover, R. Une faunule de mammifères insulaires dans le Miocène moyen de Majorque (Îles Baléares). Geobios 1982, 15, 451-463.

19. Mazza, P. Prolagus apricenicus and Prolagus imperialis: Two new ochotonids (Lagomorpha, Mammalia) of the Gargano (southern Italy). Boll Soc. Paleontol. Ital. 1987, 26, 233-243.

20. Fladerer, F.A.; Fiore, M. The Early Pleistocene insular hare Hypolagus peregrinus sp. nov. from Northern Sicily. Paleontogr. Ital. 2003, 89, 37-63.

21. Quintana, J.; Bover, P.; Alcover, J.A.; Agustí, J.; Bailon, S. Presence of Hypolagus Dice, 1917 (Mammalia, Lagomorpha) in the Neogene of the Balearic Islands (Western Mediterranean): Description of Hypolagus balearicus nov. sp. Geobios 2010, 43, 555-567, doi:10.1016/j.geobios.2010.03.003.

22. Quintana, J.; Köhler, M.; Moyà-Solà, S. Nuralagus rex, gen. et sp. nov., and endemic insular giant rabbit from the Neogene of Minorca (Balearic Islands, Spain). J. Vertebr. Paleontol. 2011, 31, 231-240, doi:10.1080/02724634.2011.550367.

23. Angelone, C.; Čermak, S.; Rook, L. New insights on Paludotona, an insular endemic lagomorph (Mammalia) from the TuscoSardinian palaeobioprovince (Italy, Turolian, Late Miocene). Riv. Ital. Paleontol. S 2017, 123, 455-473. 10.13130/2039-4942/9082.

24. Angelone, C.; Čermak, S.; Moncunill-Solé, B.; Quintana, J.; Tuveri, C.; Arca, M.; Kotsakis, T. Systematics and paleobiogeography of Sardolagus obscurus n. gen. n. sp. (Leporidae, Lagomorpha) from the early Pleistocene of Sardinia. J. Paleontol. 2018, 92, 506522. 10.1017/jpa.2017.144.

25. Smith, A.T.; Johnston, C.H.; Alves, P.C.; Hackländer, K. Lagomorphs. Pikas, Rabbits and Hares of the World, 1st ed.; Johns Hopkins University Press: Baltimore, MD, USA, 2018.

26. Angelone, C.; Moncunill-Solé, B.; Kotsakis, T. Fossil Lagomorpha (Mammalia) of Italy: Systematics and biochronology. Riv. Ital. Paleontol. S 2020, 126, 157-187. 10.13130/2039-4942/13014.

27. Dawson, M.R. Osteology of Prolagus sardus, a Quaternary ochotonid (Mammalia, Lagomorpha). Palaeovertebrata 1969, 2, 157190.

28. Angelone, C. Evolutionary trends of the genus Prolagus (Ochotonidae, Lagomorpha) in the Mediterranean Islands. In Proceedings of the International Symposium "Insular Vertebrate Evolution: The Palaeontological Approach"; Alcover, J.A., Bover, P., Eds.; Societat d'Històrica Natural de les Balears: Palma de Mallorca, Spain, 2005; Volume 12, pp. 17-26.

29. Angelone, C. Messinian Prolagus (Ochotonidae, Lagomorpha) of Italy. Geobios 2007, 40, 407-421, doi:10.1016/j.geobios.2006.04.004.

30. Quintana, J.; Agustí, J. Los mamíferos del Mioceno medio y superior de Menorca (Islas Baleares, Mediterráneo occidental). Geobios 2007, 40, 677-687, doi:10.1016/j.geobios.2006.11.007.

31. Angelone, C.; Tuveri, C.; Arca, M.; López Martínez, N.; Kotsakis, T. Evolution of Prolagus sardus (Ochotonidae, Lagomorpha) in the Quaternary of Sardinia Island (Italy). Quat. Int. 2008, 182, 109-115, doi:10.1016/j.quaint.2007.08.020.

32. Angelone, C.; Čermak, S.; Kotsakis, T. The most ancient lagomorphs of Sardinia: An overview. Geobios 2015, 48, $287-296$.

33. Moncunill-Solé, B.; Tuveri, C.; Arca, M.; Angelone, C. Comparing the body mass variations in endemic insular species of the genus Prolagus (Ochotonidae, Lagomorpha) in the Pleistocene of Sardinia. Riv. Ital. Paleontol. S 2016, 122, 26-36, doi:10.13130/2039-4942/6905.

34. Moncunill-Solé, B.; Orlandi-Oliveras, G.; Jordana, X.; Rook, L.; Köhler, M. First approach of the life history of Prolagus apricenicus (Ochotonidae, Lagomorpha) from Terre Rosse sites (Gargano, Italy) using body mass estimation and paleohistological analysis. C R. Palevol. 2016, 15, 235-245, doi:10.1016/j.crpv.2015.04.004.

35. Moncunill-Solé, B. Eco-evolutionary adaptations of ochotonids (Mammalia: Lagomorpha) to islands: New insights into Late Miocene pikas from the Gargano palaeo-archipelago (Italy). Biol. J. Linn. 2021, 132, 400-412, doi:10.1093/biolinnean/blaa157. 
36. Zoboli, D.; Zedda, M.; Pillola, G.L.; Palombo, M.R. Does a relationship exist between palaeopathologies and insularity? A case study of some bones of Prolagus sardus (Wagner, 1829) from Sardinia (Italy). Alp Mediterr. Quat. 2018, 31, 75-86, doi:10.26382/AMQ.2018.12.

37. Lomolino, M.V.; van der Geer, A.A.; Lyras, G.A.; Palombo, M.R.; Sax, D.F.; Rozzi, R. Of mice and mammoths: Generality and antiquity of the island rule. J. Biogeogr. 2013, 40, 1427-1438, doi:10.1111/jbi.12096.

38. van der Geer, A.A.; Lyras, G.A.; Lomolino, M.V.; Palombo, M.R.; Sax, D.F. Body size evolution of palaeo-insular mammals: Temporal variations and interspecific interactions. J. Biogeogr. 2013, 40, 1440-1450, doi:10.1111/jbi.12119.

39. van den Hoek Ostende, L.W.; van der Geer, A.A.E.; Wijngaarden, C.L. Why are there no giants at the dwarves feet? Insular micromammals in the eastern Mediterranean. Quat. Int. 2017, 445, 269-275, doi:10.1016/j.quaint.2016.05.007.

40. van der Geer, A.; Lyras, G.; de Vos, J.; Dermitzakis, M. Evolution of Island Mammals. Adaptation and Extinction of Placental Mammals on Islands, 1st ed.; Wiley-Blackwell: Oxford, UK, 2010.

41. Hautier, L.; Bover, P.; Alcover, J.A.; Michaux, J. Mandible morphometrics, dental microwear pattern, and paleobiology of the extinct Balearic dormouse Hypnomys morpheus. Acta Paleontol. Pol. 2009, 54, 181-194, doi:10.4202/app.2008.0001.

42. Sondaar, P.Y. Insularity and its effect on mammal evolution. In Major Patterns in Vertebrate Evolution; Hecht, M.K., Goody, P.C., Hecht, B.M., Eds.; Plenum Publishing Corporation: New York, NY, USA, 1977; pp. 233-256.

43. Alcover, J.A.; Moyà-Solà, S.; Pons-Moyà, J. Les quimeres del passat: Els vertebrats fòssils del Plio-Quaternari de les Balears $i$ Pitiüses; Moll: Ciutat de Mallorca, Spain, 1981.

44. Quintana, J.; Moncunill-Solé, B. Reconsidering locomotor habits and life style of the Balearic insular giant rodent Hypnomys Bate, 1918 from the allometry of the limb long bones. C R. Palevol. 2014, 13, 297-306, doi:10.1016/j.crpv.2013.11.003.

45. Orlandi-Oliveras, G.; Jordana, X.; Moncunill-Solé, B.; Köhler, M. Bone histology of the giant fossil dormouse Hypnomys onicensis (Gliridae, Rodentia) from Balearic Islands. C R. Palevol. 2016, 15, 247-253, doi:10.1016/j.crpv.2015.05.001.

46. Leack, K.; Kelly, R.; Cameron, A.; Montgomery, W.I.; Reid, N. Expertly validated models and phylogenetically-controlled analysis suggests responses to climate change are related to species traits in the Order Lagomorpha. PLoS ONE 2015, 10, e0122267, doi:10.1371/journal.pone.0122267.

47. Dietl, G.P.; Kidwell, S.M.; Brenner, M.; Burney, D.A.; Flessa, K.W.; Jackson, S.T.; Koch, P.L. Conservation Paleobiology: Leveraging knowledge of the past to inform conservation and restoration. Annu. Rev. Earth Planer Sci. 2015, 43, 79-103, doi:10.1146/annurev-earth-040610-133349.

48. Smith, A. Conservation status of American pikas (Ochotona princeps). J. Mammal. 2020, 101, 1466-1488, doi:10.1093/jmammal/gyaa110. 